\title{
1 Glacier extent and climate in the Maritime Alps during the Younger Dryas
}

2 Matteo Spagnolo ${ }^{1}$, Adriano Ribolini ${ }^{2}$

$3{ }^{1}$ School of Geosciences, University of Aberdeen (UK) (corresponding author: $\underline{\text { m.spagnolo@abdn.ac.uk) }}$

$4 \quad 2$ Dipartimento di Scienze della Terra, Universita' di Pisa (Italy)

5

6

7

8

9

10

11

Keywords: Younger Dryas; glacier reconstruction; equilibrium line altitude; palaeoclimate; cosmogenic dates; Maritime Alps

\section{Abstract}

This study focuses on an Egesen-stadial moraine located at 1906-1920 m asl in the NE Maritime Alps, Europe. Three moraine boulders are dated, via cosmogenic isotope analyses, to $12,490 \pm 1120,12,260$ \pm 1220 and $13,840 \pm 1240 \mathrm{yr}$, an age compatible with the Younger Dryas cooling event. The reconstructed glacier that deposited the moraine has an equilibrium line altitude of $2349 \pm 5 \mathrm{~m}$ asl, calculated with an Accumulation Area Balance Ratio of 1.6. The result is very similar to the equilibrium line altitude of another reconstructed glacier that deposited a moraine also dated to Younger Dryas, in the SW Maritime Alps. The similarity suggests comparable climatic conditions across the region during the cooling event. The Younger Dryas palaeoprecipitation is $1549 \pm 26 \mathrm{~mm} / \mathrm{yr}$, calculated using the empirical law that links precipitation and temperature at a glacier equilibrium line altitude, with palaeotemperatures obtained from nearby palynological and chironomids studies. The palaeoprecipitation is similar to the present, thus indicating non-arid conditions during the Younger Dryas. This is probably due to the Maritime Alps peculiar position, at the crossroads between air masses from the Mediterranean and the North Atlantic, the latter displaced by the southward migration of the polar front. The equilibrium line altitude interval defined by the two reconstructed glaciers, is used to model the extent of another 66 potential Younger Dryas glaciers in the region. Each modelled glacier is reconstructed by iteratively changing the position of its front until the reconstructed glacier has an ELA that falls within the interval. The result, which is checked against geomorphological evidence, shows that glaciers covered $83.74 \mathrm{~km}^{2}$ during the Younger Dryas, with a volume of $5.39 \mathrm{~km}^{3}$. All valley heads were occupied by ice, except for the Maddalena/Larche Pass (1999 $\mathrm{m}$ asl), an ideal site for future archaeological, palaeoecological and palaeozoological studies.

1. Introduction

The Younger Dryas (YD) is the most recent time in our planet's history during which a cooling of the order of some degrees affected a large portion of the Earth, triggered by several climatic processes (Renssen et al., 2015). It occurred at the end of the last glacial period, between 12.9 and $11.7 \mathrm{kyr}$ (e.g. Johnsen et al., 2001; Broecker et al, 2010). The critical assemblage of several sources has suggested that the cooling magnitude of this event was of the order of $2-8^{\circ} \mathrm{C}$ in the Northern Hemisphere (Shakun and Carlson, 2010), with variations likely controlled by local climatic factors. One 
of the most evident effects of the YD cooling on the Earth's surface is the widespread advancement of alpine glaciers and the deposition of moraines. The lack of post-YD cooling events of similar or larger magnitude, means that YD moraines are usually well preserved, as they have not been destroyed or remoulded by the overriding of later glacier advances. Indeed, moraines dated back to the YD can be found in many alpine regions worldwide (Ehlers and Gibbard, 2004). The European Alps are one of the first regions where YD moraines have been identified and dated. Here, moraines belonging to the Alpine glacier advance (or chronology stadial) known as the Egesen stadial have been recognised and studied for a long time (e.g. Heuberger, 1968; Patzelt, 1972). The age of the Egesen moraines has been attributed to the YD, initially via morphotratigraphic reconstructions and, in recent decades, by means of cosmogenic isotope nuclide dating techniques (e.g. Ivy-Ochs et al., 1996; 2009).

Frontal (terminal) moraines are the essential ingredient for the reconstruction of former Alpine glaciers, as they indicate the furthest downvalley position (limit or margin) of the glacier. Models can be applied to reconstruct the full extent of palaeo glaciers, given the location of a frontal moraine and the present-day topography, assuming the latter has not undergone intense post-glacial modifications (e.g. Benn and Hulton, 2010). The ice surface distribution per elevation (hypsometry) of reconstructed glaciers can then be used to extract a palaeo Equilibrium Line Altitude (ELA), the elevation on a glacier where ice ablation and accumulation are equal (Osmaston, 2005). Modern glacier ELAs have been empirically demonstrated to relate to climate, precipitation and temperature in particular (e.g. Ohmura et al., 1992). Thus, a palaeo ELA obtained from a glacier reconstruction based on a dated glacial deposit can be used to infer the climatic conditions at the time of deposition of the moraine (e.g. Hughes et al., 2007).

In order to fully analyse the palaeogeography of an alpine region and to quantify palaeo ice extent and volume at a specific time, ideally all palaeoglaciers occupying the region at that time should be reconstructed. Examples of region-wide glaciers reconstruction in alpine contexts exist, but are usually limited to large ice caps and ice fields modelling exercises, more or less constrained by terrain evidence (e.g. for the last glacial cycle in the Alps: Seguinot et al., 2018; for the LGM in the Alps: Florineth and Schlüchter, 1998; Bini et al., 2009; Ehlers and Gibbard, 2004; for the YD in Scotland: Golledge et al., 2008; Boston et al., 2015). Regional model reconstructions are useful not only to gain insight into the glaciological response to past climate changes but also to understand human activities and behaviours (migrations, trading, land reclamation etc.) (e.g. Catto et al., 1996; Meyer et al., 2009; Ravazzi et al., 2007; Serrano et al., 2015), as well as fauna and flora dynamics (e.g. extinctions, glacial refugia, etc.) (e.g. Badino et al., 2018; Casazza et al., 2016; Garnier et al., 2004; Schönswetter et al., 2005; Schorr et al., 2013; Stehlik, 2003). They also provide essential information to explain changes or 
hiatuses in other palaeoclimate proxies, for example in alpine lake deposits and speleothems (e.g. Spotl and Mangini, 2007; van der Bilt et al., 2018; Isola et al., 2019).

Here, we present an Egesen moraine in the Maritime Alps (southwestern-most European Alps) dated to the YD by means of cosmogenic isotope analyses. We reconstruct the extent of the glacier that deposited the moraine and we calculate its ELA. The result is combined with the ELA of another, already reconstructed glacier, which deposited the YD-dated Pian del Praiet (PDP) moraine (Federici et al., 2008), located some $40 \mathrm{~km}$ ESE, to define a regional YD ELA for the Maritime Alps. This is used to extract the palaeoclimate conditions of the region at the YD and to reconstruct all potential YD glaciers (66) in one of the main valley systems of this Alpine sector.

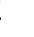

83

\section{Regional context}

The Maritime Alps are the southernmost (latitude of $43.9-44.4^{\circ} \mathrm{N}$; longitude of $6.9-7.6^{\circ} \mathrm{E}$ ) portion of the European Alps, very close $(40-60 \mathrm{~km})$ to the Mediterranean Sea (hence the term "Maritime") and yet with elevations exceeding $3000 \mathrm{~m}$ asl (Figure 1). They are drained by four rivers, which give name to the four main valleys of the region. These are the Tinée, Vesubié, Gesso and Stura (di Demonte) rivers. The first two are located on the southwestern side of the Maritime Alps and drain southward to the Ligurian Sea, while the last two, located on the northeastern side, ultimately drain eastward, into the Po River and the Adriatic Sea. The Maritime Alps have been extensively glaciated during Marine Isotope Stage 2, in line with the global Last Glacial Maximum (26-19 kyr) (Clark et al., 2009; Shakun and Carlson, 2010; Hughes et al., 2013), when glaciers covered all main valleys and extended towards, but did not reach, the Po Plain (Italy) to the north and the coast near Nice (France) to the south (Bigot-Cormier et al., 2005; Federici et al., 2012). While a number of moraines mapped in the Maritime Alps have been hypothesised to belong to the Late Pleistocene (Federici et al., 2003), only PDP moraine, located in the Gesso catchment, has so far been dated to the YD event (average age of $13.2 \pm 0.9 \mathrm{kyr}$ ) (Federici et al., 2008; 2017).

Present-day precipitations are bimodal, with peaks in spring and autumn, and are generally lower than in the nearby northern Apennines and the rest of the Alps (Isotta et al., 2014). Temperatures are unimodal with a summer peak, and generally higher than in other, nearby Alpine regions (Durand et al., 2009). Differences exist across the main divide, with the southern side of the Maritime Alps generally characterised by warmer temperatures than in the northern side (Auer et al., 2007). However, within the studied region of interest, which lies entirely in the norther sector, similar present-day climate conditions exist. This work focuses on the Stura catchment (Figure 1), one of the largest in the southwestern Alps, comprising dozens of Alpine glacial valleys (currently ice-free), 
covering an area of $615 \mathrm{~km}^{2}$. The southern sector of the Stura catchment is generally characterised by the crystalline rocks of the Argentera Massif, while its northern sector is made of sedimentary and metasedimentary rock units (Malaroda et al., 1970). Tectonics has played a key control function on the geometry development of these valleys (Ribolini, 2000; Musumeci et al., 2003, Ribolini and Spagnolo, 2008). The dated moraine presented in this paper is in the Forneris Valley (Figure 1), in the northern sector of the Stura catchment, at an elevation of 1908-1922 m asl. The upper valley, 3-3.5 $\mathrm{km}$ from the moraine, is characterised by peaks reaching $>2700 \mathrm{~m}$ asl and comprises four glacial cirques and a number of rock glaciers and glacial deposits. The specific lithology of the Forneris Valley

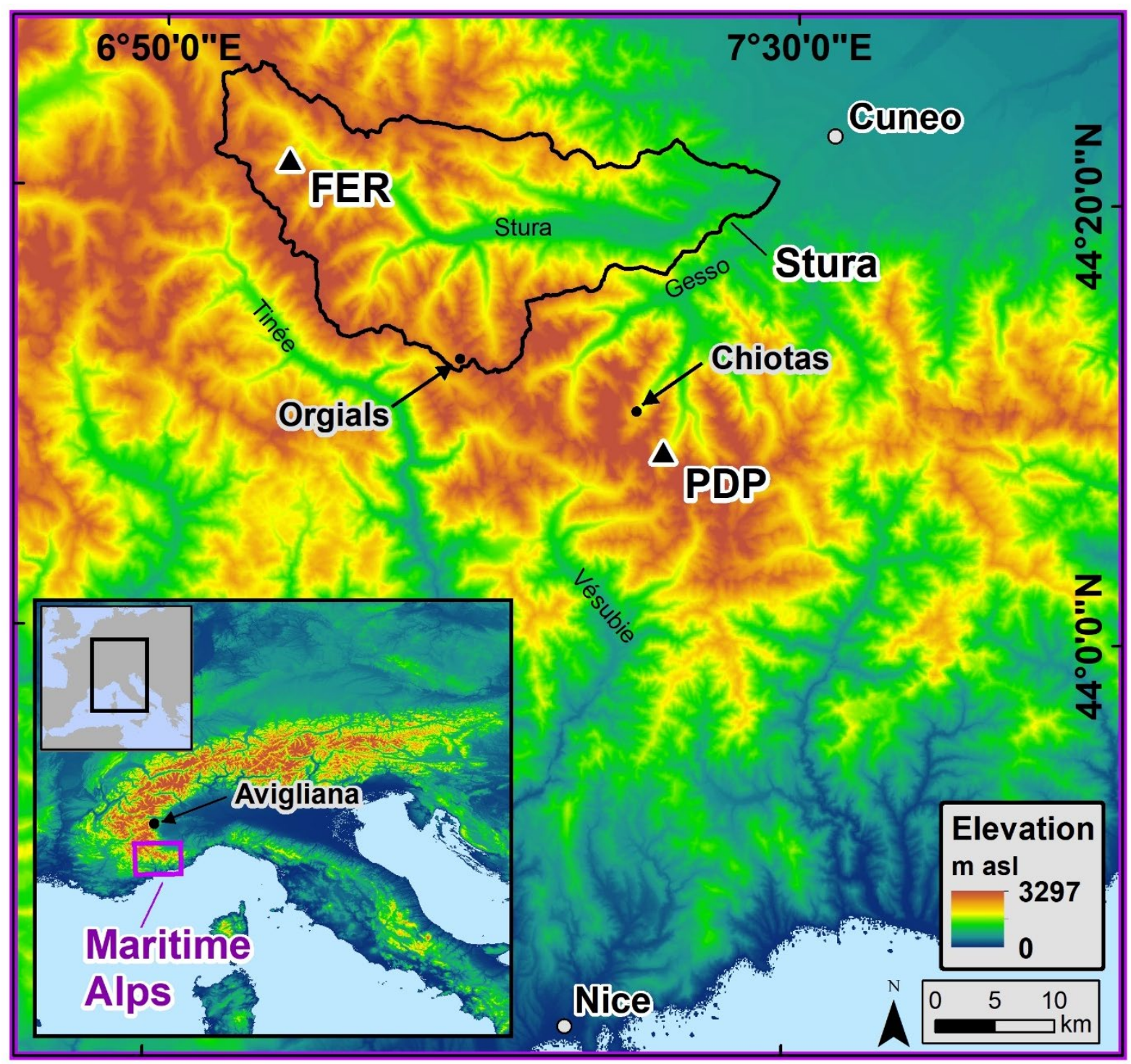

Figure 1. An overview of the Maritime Alps and the Stura catchment within it (outlined in black). The location of the two moraines discussed in the text, PDP and FER (the latter in the Forneris Valley), is indicated, as well as that of the chironomid site of Lago Piccolo di Avigliana ("Avigliana" in the figure), the pollen site of Laghi dell'Orgials ("Orgials"), and the present-day weather station of the Diga del Chiotas ("Chiotas"). The cities of Nice and Cuneo are shown to provide geographical references. The Mediterranean Sea is evidenced in light blue. 
3. Methods

124

125

126

127

128

129

130

131

132

133

134

135

136

137

138

139

140

141

142

143

144

145

146

147

148

149

150

151

152

153

154

155

\subsection{Chronology}

The Ferrere (FER) moraine is located in the Forneris Valley, Stura catchment, near the village of Ferrere (Figure 1). A total of 10 samples were collected from the moraine during two field campaigns in 2011 and 2013. The <3-cm-thick samples were collected with hammer and chisel from the upper, gently-sloping or horizontal, surface of large gneiss boulders located along the moraine crest and emerging more than $1.5 \mathrm{~m}$ above the ground (Table 1 and Figure 2). Samples were crushed and quartz grains extracted by using the standard ${ }^{10} \mathrm{Be}$ cosmogenic isotope analysis procedure (Kohl and Nishizumi, 1992). Only 3 of the 10 samples revealed enough quartz of the right grain size for the content of the isotope ${ }^{10} \mathrm{Be}$ to be measured. Measurements took place at the Natural Environment Research Council - Cosmogenic Isotope Analysis Facility in the UK, with the use of the $2.7910^{-11}$ ${ }^{10} \mathrm{Be} /{ }^{9} \mathrm{Be}$ of Nishiizumi et al. (2007) for NIST 206 SRM4325 (NIST_27900 standardisation code, equivalent to 07KNSTD). Reported exposure ages are calculated with the CRONUS-earth online calculator version 2.3 , using a default calibration data set and the time-independent Lal/Stone spallation scheme.

\subsection{Glacial reconstruction and ELA calculation}

Glacier reconstructions in this paper are based on the application of a dedicated GIS tool, "GlaRe" (Pellitero et al., 2016). The tool creates a 3D glacier surface based on the lateral interpolation of a 2D glacier equilibrium profile, which is calculated by using a plastic rheology glacier model along a user-defined flowline(s) (Benn and Hulton, 2010; Paterson, 1994, p.240; Shilling and Hollin, 1981). Glaciers are reconstructed by extrapolating the ice thickness along the defined flowlines every $5 \mathrm{~m}$, and by applying a default shear stress of $100 \mathrm{kPa}$. Shape (F) factors (usually between 1 and 5), accounting for the width of the glacial valley, are also included where appropriate, i.e. at different points of valley narrowing. For each reconstructed glacier, the final GlaRe output is a 3D glacier terrain model, which is obtained by interpolating sideways the ice thickness calculated along the flowlines, using a "TOPOtoRASTER" interpolation approach (Pellitero et al., 2016). The reconstructed 3D glacier terrain model is then used to extract the ELA of the glacier, through a separate GIS tool (Pellitero et al., 2015). While the tool allows for most ELA calculation techniques to be implemented, for the sake of consistency all our ELA calculations are based on the same technique, that of the Accumulation Area Balance Ratio (AABR) (Furbish and Andrews, 1984), with an AABR value of 1.6, as recommended for the Alps (Rea; 2009). AABR is considered one of the most robust techniques because it takes into consideration both the hypsometry of the glacier surface (Osmaston, 2005) and the mass balance 
gradients (Benn and Lehmkuhl, 2000). A contour interval of $10 \mathrm{~m}$ is set for the calculation of the glacier surface area, meaning that all extrapolated ELA values have an associated calculation interval of \pm 5 m (Pellitero et al., 2015).

A regional YD ELA interval is defined, based on the two ELAs values relative to glaciers that deposited moraines dated to the YD (PDP and FER) in the Maritime Alps. The YD PDP moraine (Federici et al., 2008) is located $\sim 40 \mathrm{~km}$ to the SE of the FER moraine (Figure 1). The YD ELA interval is then used to model the extent of all Stura catchment potential YD glaciers, which are largely located between the two dated moraines (Figure 1). The modelled reconstruction is based on the application of the GIS GlaRe and ELA tools (Pellitero et al., 2015, 2016) to all Stura glacial valleys. For each valley the tools are run multiple times, iteratively moving up- or down-valley the hypothetical position of a glacier front, until the reconstructed glacier returns an ELA value that fits within the defined regional YD ELA interval. The approach is similar to that of Rea and Evans (2007) but is improved by the employment of the GIS tools. The modelled position of the glaciers front was checked against evidence of frontal moraines and glacial deposits from field observations, Quaternary information included in geological maps (Malaroda et al., 1970) and remote sensing (Google Earth ${ }^{\mathrm{TM}}$ ).

\subsection{Palaeoclimatology}

The climatological study is focused on the extraction of palaeoprecipitation at the YD ELA (average of the two ELAs obtained from the reconstructed glaciers that deposited moraines dated back to the YD in the Maritime Alps). This study is based on the empirical law connecting annual precipitation ( $P_{\mathrm{ann}}$ in $\mathrm{mm}$ ) and mean air temperature during the melting period (the summer in our case, $T_{\text {melt }}$ ) at the ELA, following the equation $P_{a n n}=5.87 \mathrm{~T}_{\text {melt }}{ }^{2}+230 \mathrm{~T}_{\text {melt }}+966$ (Ohmura and Boettcher, 2018). The temperature of the hottest month $\left(T_{j u l}\right)$ for the YD in the region is sourced from chironomids (midges), a fossil palaeotemperature proxy commonly found in freshwater lake deposits. The chironomid series closest to the Maritime Alps and covering the YD period is found $95 \mathrm{~km}$ to the north, at Lago Piccolo di Avigliana $\left(45.0549^{\circ} \mathrm{N}, 7.3919^{\circ} \mathrm{E} ; 365 \mathrm{~m}\right.$ asl) (Larocque and Finsinger, 2008). At this site, the average $Y D T_{J u l}$ is $16.3^{\circ} \mathrm{C}$. In order to adjust this value to the elevation of the YD average ELA we apply the present-day global lapse rate $\left(6.5^{\circ} \mathrm{C} / 1 \mathrm{~km}\right)$. While $T_{\text {Jul }}$ is a good proxy for the maximum monthly temperature and is very close to $T_{\text {melt, }}$, for a precise calculation of the latter, $T_{\text {Jun }}$ and $T_{\text {Aug }}$ also need to be taken into account and the temperature of the three months averaged. This is achieved here by fitting a sine curve to the value of $\mathrm{T}_{\mathrm{Jul}}$ and to the minimum monthly temperature ( $\left.T_{\text {Jan }}\right)$ (Brugger, 2006; Hughes and Braithwaite, 2008). The latter is obtained from a pollen study conducted in one of the many lakes of the Stura catchment, the Orgials Lake, at $2240 \mathrm{~m}$ asl (Figure 1) (Ortu et al., 2008). The average $Y D \mathrm{~T}_{\mathrm{Jan}}$ for this site is $-16.9^{\circ} \mathrm{C}$, which is adjusted to the elevation of the 
calculated YD ELA by using the standard lapse rate of $6.5^{\circ} \mathrm{C} / 1 \mathrm{~km}$. An attempt was also made to calculate $T_{\text {melt }}$ with a different approach, based on a combination of the same chironomid data mentioned above and sea surface temperatures measured in northern Sicily (Cacho et al., 2001) and adjusted for the latitude and altitude of the ELA. However, the result is very similar to that obtained when combining chironomids with pollen data and, for the sake of clarity, we prefer to focus on the latter, which is based on proxies collected within or relatively close to the region of study.

In order to put the reconstructed YD palaeoclimate into context, we compare our calculation with present day measurements from a site within the Maritime Alps characterised by an elevation relatively close to the YD average ELA, namely the Diga del Chiotas weather station, which is at 1980 $\mathrm{m}$ asl (Figure 1). Total annual precipitation, as well as January, July and summer (June-August) temperatures are averaged from 2001 to 2018 measurements. The measured temperatures are adjusted to the elevation of the calculated YD ELA by applying the standard lapse rate of $6.5^{\circ} \mathrm{C} / 1 \mathrm{~km}$.
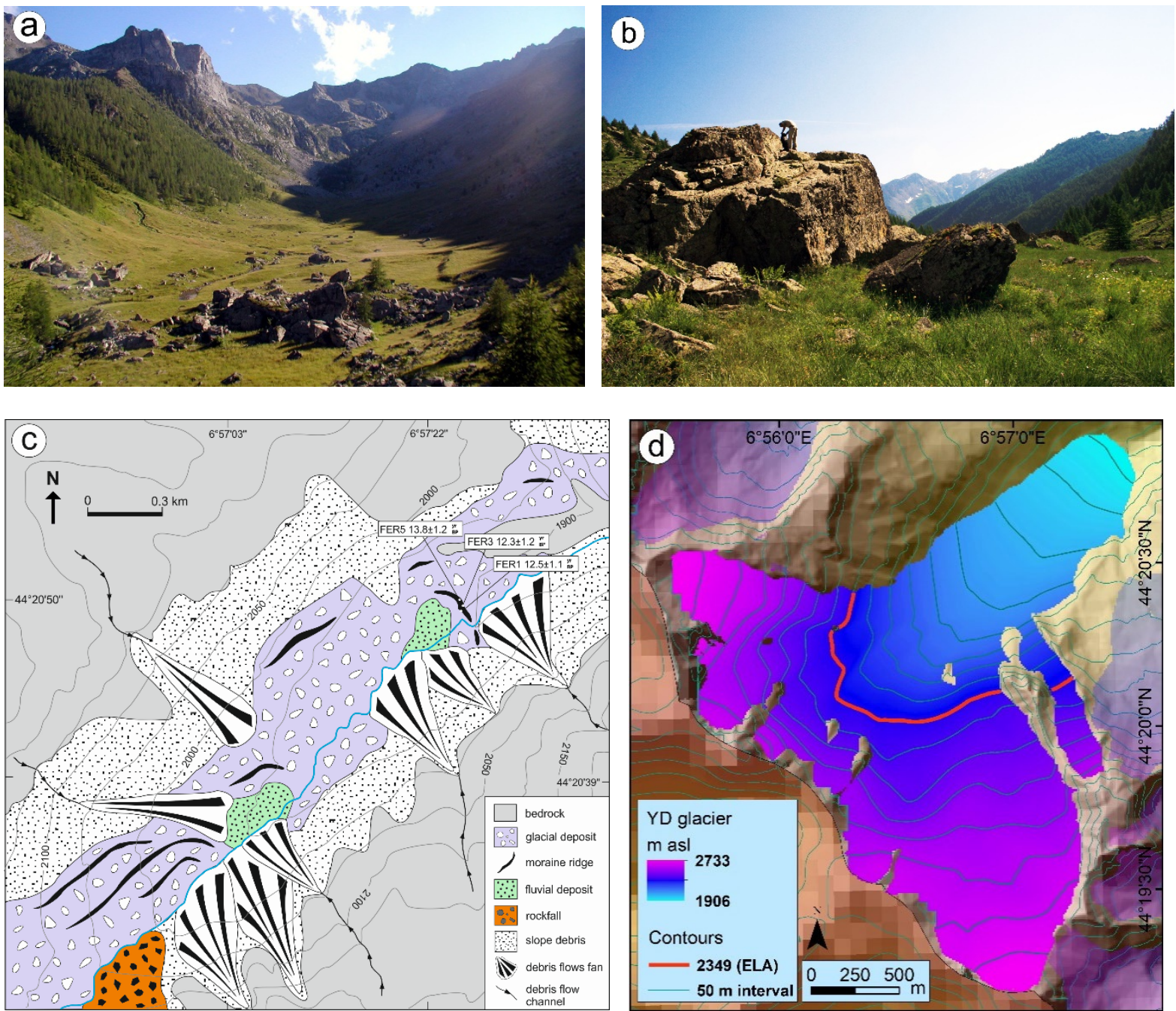

Figure 2 An overview of the Ferrere moraine and of the Forneris glacier: (a) Val Forneris and Ferrere moraine in the foreground; (b) FER3 sampled boulder on the crest of the moraine (notice one of us over its top for scale); (c) geomorphological map of the Ferrere moraine and surroundings, with indication of the position of the three 
dated boulder samples; (d) reconstructed YD Forneris glacier that deposited the Ferrere moraine and the calculated YD ELA (thick red line) obtained by using the AABR technique.

\section{Results}

\subsection{The Ferrere moraine and its age}

FER is mainly composed of diamicton, with small (cms to dms) blocks immersed in abundant fine sediments. However, the most distinct trait of FER is the presence of a few, very large, angular blocks, with dimensions of up to 8 meters (Figure 2a, b). The blocks stand out of the ground and are aligned for about $350 \mathrm{~m}$ following a classic arcuate shape, typical of many marginal moraines. The frontal moraine deposit has clearly acted as a barrier to the natural flow of the main river, which now cuts the moraine into two halves. The relatively flat area right upvalley from the moraine is therefore characterised by a mixture of diamicton and fluvial sediments. The portion of other, less well preserved, lateral and frontal moraines exists in the immediate ( $500 \mathrm{~m}$ ) surroundings of FER (Figure 2c), thus suggesting that multiple, most likely related to the same climatic event, glacier fluctuations (retreats and re-advances to a similar position) have occurred.

The Ferrere moraine samples, FER1, FER3 and FER5, returned ages of $12,490 \pm$ (external uncertainty, i.e. the sum of accelerator mass spectrometry measurement and production rate uncertainties) $1120 \mathrm{yr}, 12,260 \pm 1220 \mathrm{yr}$ and 13,840 $\pm 1240 \mathrm{yr}$, respectively (Table 1 ). All three ages overlap in the $12,605-13,476 \mathrm{yr}$ interval, with a weighted mean ( \pm weighted standard deviation) of $12,950 \pm 700 \mathrm{yr}$ (calculated with iceTEA, Jones et al., 2019), and are therefore compatible with the YD timeframe. The FER ages are also similar to those of the other Maritime Alps moraine (PDP) dated back to the YD, which returned an average age of 13,174 yr (Federici et al., 2017).

\begin{tabular}{|c|c|c|c|c|c|c|c|c|c|c|c|c|c|c|c|}
\hline $\begin{array}{c}\text { Sample } \\
\text { name }\end{array}$ & \begin{tabular}{|l} 
rock \\
type
\end{tabular} & \begin{tabular}{|l} 
Latitude \\
(degree)
\end{tabular} & $\begin{array}{c}\text { Longitude } \\
\text { (degree) }\end{array}$ & $\begin{array}{c}\text { boulder } \\
\text { height }(\mathrm{m})\end{array}$ & $\begin{array}{c}\text { strike } \\
\text { (N) }\end{array}$ & $\begin{array}{l}\text { dip } \\
\left({ }^{\circ}\right)\end{array}$ & $\begin{array}{c}\text { Elevation } \\
\text { (m asl) }\end{array}$ & $\begin{array}{c}\text { Thickness } \\
(\mathrm{cm})\end{array}$ & \begin{tabular}{|l|} 
Density \\
$(\mathrm{g} / \mathrm{cm} 3)$
\end{tabular} & $\begin{array}{c}\text { Shielding } \\
\text { factor }\end{array}$ & $\begin{array}{c}{ }^{10} \text { Be concentration } \\
\text { (at } / g)\end{array}$ & $\begin{array}{l}{ }^{10} \text { Be uncertainty } \\
\text { (at/g) }\end{array}$ & \begin{tabular}{|l}
${ }^{10} \mathrm{Be}$ age \\
yr BP
\end{tabular} & $\begin{array}{c}\text { internal } \\
\text { uncertainty (yr) }\end{array}$ & $\begin{array}{c}\text { external } \\
\text { uncertainty (yr) }\end{array}$ \\
\hline FER1 & gneiss & \begin{tabular}{|l|l|l|} 
\\
\end{tabular} & 6.957441 & $1.5-2.5$ & horiz. & flat & 1908 & $<3$ & 2.65 & 0.943 & 215,914 & 5,528 & 12,489 & 321 & 1117 \\
\hline FER3 & gneiss & 44.347302 & 6.957648 & $3-6$ & 310 & $8 \mathrm{SW}$ & 1916 & $<3$ & 2.65 & 0.942 & 213,360 & 10,774 & 12,257 & 621 & 1219 \\
\hline FER5 & gneiss & 44.347483 & 6.957622 & $2-5$ & 70 & $20 \mathrm{SE}$ & 1915 & $<3$ & 2.65 & 0.933 & 238,158 & 6,086 & 13,843 & 355 & 1238 \\
\hline
\end{tabular}

Table 1 Detail of the three boulder samples from the moraine near the village of Ferrere, in Val Forneris, including their ${ }^{10} \mathrm{Be}$ concentration and exposure age.

\subsection{YD glaciers and ELA in the Maritime Alps}

Identification of the Ferrere moraine, along with other glacial features, allowed for the reconstruction of the glacier responsible for its deposition, called here the Forneris glacier after the name of the valley. The reconstructed YD Forneris glacier (Figure $2 \mathrm{~d}$ ) has a length of $3.6 \mathrm{~km}$ from its margin (at $1906 \mathrm{~m}$ asl) to a point close to the valley divide (at $\sim 2733 \mathrm{~m}$ asl), covering an elevation range of $827 \mathrm{~m}$. The glacier surface is $3.89 \mathrm{~km}^{2}$ and its volume is $0.19 \mathrm{~km}^{3}$. The YD (AABR) ELA for the reconstructed Forneris glacier is $2349 \pm 5 \mathrm{~m}$ asl. The ELA of the other Maritime Alps glacier with a moraine (PDP) dated to the YD, reconstructed with the same approach used here, is $2368 \pm 5 \mathrm{~m}$ asl 
(Federici et al., 2017). The two ELAs define a Maritime Alps YD ELA interval of 2344-2373 m asl, with

246 an average value of $2358 \pm 15 \mathrm{~m}$ asl. The extent of 66 other potential YD glaciers was modelled across

247 the Stura catchment by iteratively changing their frontal position until their ELA fell within the 2344-

$2482373 \mathrm{~m}$ asl interval (Figure 3 and Table 2). The area of the 66 glaciers ranges from $0.07 \mathrm{~km}^{2}$ (Lake

249 Sauma glacier) to $5.99 \mathrm{~km}^{2}$ (Bernolfo glacier). Collectively, their area is $83.74 \mathrm{~km}^{2}$ and the volume is

$2505.39 \mathrm{~km}^{3}$, equivalent to $4.94 \mathrm{Gt}$ of water.

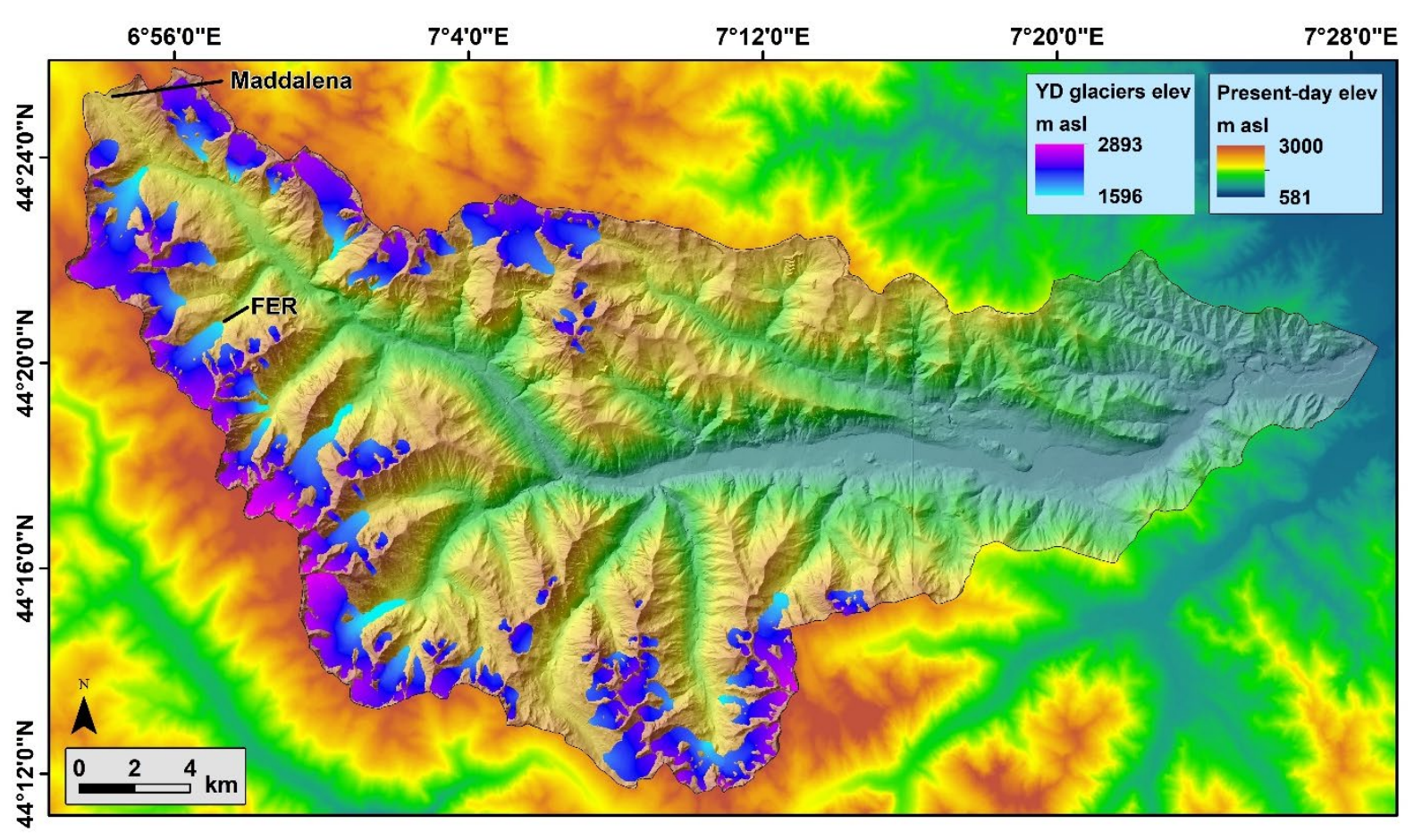

Figure 3 The 66 reconstructed YD glaciers in the Stura catchment of the Maritime Alps. "FER" indicates the position of the Ferrere moraine, while "Maddalena" (or Larche) refers to the major ice-free pass across this sector of the Alps at the YD.

\subsection{Palaeo- and present-day climate at the Maritime Alps YD ELA}

The YD average $T_{\text {Jul }}$ at $2358 \pm 15 \mathrm{~m}$ asl, the Maritime Alps YD ELA, calculated from the Lago Piccolo di Avigliana chironomid study (Larocque and Finsinger, 2008), is $3.3 \pm 1{ }^{\circ} \mathrm{C}$. The YD average $\mathrm{T}_{\mathrm{Jan}}$, obtained from the Lago dell'Orgials pollen study (Ortu et al., 2008), is $-17.7 \pm 0.1{ }^{\circ} \mathrm{C}$, thus defining a seasonality $\left(\mathrm{T}_{\mathrm{Jul}}-\mathrm{T}_{\mathrm{Jan}}\right)$ of $21.0^{\circ} \mathrm{C}$. With this, it is possible to estimate a $\mathrm{T}_{\text {melt }}$ of $2.4 \pm 1{ }^{\circ} \mathrm{C}$ and a $\mathrm{P}_{\text {ann }}$ of 


\begin{tabular}{|c|c|c|c|c|c|c|}
\hline Glacier name & Longitude & Latitude & Area & \begin{tabular}{|l|} 
Volume \\
\end{tabular} & AABR ELA & Reconstructed glacier \\
\hline & $\left({ }^{\circ} \mathrm{E}\right)$ & $\left({ }^{\circ} \mathrm{N}\right)$ & $\left\{\mathrm{km}^{2}\right\}$ & $\left(\mathrm{km}^{3}\right)$ & (m asl) & front morphology \\
\hline Orgials & 7.147 & 44.210 & 2.231 & 0.107 & 2346 & Moraine \\
\hline Aver West & 7.137 & 44.223 & 0.928 & 0.037 & 2346 & - \\
\hline San Giovanni & 7.133 & 44.233 & 0.755 & 0.029 & 2351 & - \\
\hline Maladecia & 7.143 & 44.240 & 0.641 & 0.021 & 2357 & - \\
\hline Argentera & 6.942 & 44.369 & 1.389 & 0.080 & 2359 & - \\
\hline Bandia & 7.093 & 44.378 & 3.366 & 0.360 & 2352 & - \\
\hline Becco Nero & 7.075 & 44.382 & 1.733 & 0.360 & 2373 & - \\
\hline Bernolfo & 7.015 & 44.251 & 5.991 & 0.407 & 2373 & Glacial deposit \\
\hline Bersezio & 6.982 & 44.396 & 0.632 & 0.014 & 2370 & - \\
\hline Ciaval & 7.025 & 44.304 & 1.655 & 0.055 & 2354 & Moraine \\
\hline Guercia & 7.050 & 44.233 & 0.606 & 0.025 & 2369 & Glacial deposit \\
\hline Collalunga - San Bernolfo & 7.035 & 44.232 & 2.360 & 0.407 & 2348 & Moraine \\
\hline Cologna & 7.055 & 44.375 & 0.563 & 0.018 & 2356 & - \\
\hline Fauniera & 7.115 & 44.380 & 2.314 & 0.360 & 2358 & - \\
\hline Ferrere & 6.927 & 44.355 & 2.897 & 0.150 & 2351 & moraine \\
\hline Forneris & 6.945 & 44.334 & 3.893 & 0.195 & 2349 & moraine \\
\hline Malinvern & 7.186 & 44.211 & 4.727 & 0.188 & 2364 & Glacial deposit \\
\hline Paur & 7.203 & 44.227 & 1.370 & 0.052 & 2367 & moraine \\
\hline Aver East & 7.153 & 44.229 & 1.669 & 0.083 & 2360 & - \\
\hline Perdù & 7.201 & 44.237 & 0.927 & 0.031 & 2357 & - \\
\hline Martel & 7.155 & 44.240 & 0.473 & 0.083 & 2353 & Rock glacier \\
\hline Giordano & 7.031 & 44.368 & 1.881 & 0.118 & 2346 & - \\
\hline Ischiator & 7.013 & 44.277 & 2.677 & 0.112 & 2362 & Moirane \\
\hline Lose & 6.931 & 44.378 & 0.951 & 0.034 & 2361 & - \\
\hline Ciamp & 7.195 & 44.249 & 0.466 & 0.015 & 2348 & Glacial deposit \\
\hline Faniet & 6.973 & 44.341 & 0.199 & 0.005 & 2353 & - \\
\hline Ventasuso & 6.903 & 44.402 & 0.820 & 0.030 & 2358 & - \\
\hline Rocco Verde East & 6.977 & 44.335 & 0.088 & 0.001 & 2355 & Glacial deposit \\
\hline Ciaval South & 7.021 & 44.294 & 0.104 & 0.002 & 2354 & Glacial deposit \\
\hline Saletta & 7.033 & 44.278 & 0.175 & 0.004 & 2357 & Moraine \\
\hline Maladecia west & 7.127 & 44.242 & 0.088 & 0.002 & 2348 & - \\
\hline Cairiliera East & 7.154 & 44.247 & 0.203 & 0.005 & 2354 & Moraine \\
\hline Reduc & 7.244 & 44.262 & 0.832 & 0.027 & 2349 & - \\
\hline Cairiliera West & 7.147 & 44.248 & 0.046 & 0.001 & 2361 & - \\
\hline Bravaria & 7.106 & 44.261 & 0.166 & 0.004 & 2372 & Rock glacier \\
\hline Ciarnier & 7.149 & 44.260 & 0.047 & 0.001 & 2353 & Rock glacier \\
\hline Lausfer & 7.092 & 44.227 & 0.415 & 0.020 & 2364 & - \\
\hline Passo Lausfer & 7.083 & 44.234 & 0.513 & 0.018 & 2371 & - \\
\hline Mouton West & 7.089 & 44.252 & 0.131 & 0.004 & 2346 & Rock glacier \\
\hline Mouton East & 7.097 & 44.248 & 0.676 & 0.049 & 2358 & Moraine \\
\hline Steliere & 7.110 & 44.267 & 0.064 & 0.001 & 2352 & Moraine \\
\hline Pignal & 7.063 & 44.242 & 0.196 & 0.004 & 2351 & Moraine \\
\hline Lake Sauma & 7.061 & 44.245 & 0.071 & 0.001 & 2368 & Glacial deposit \\
\hline Vallonet & 7.055 & 44.244 & 0.187 & 0.006 & 2360 & Moraine \\
\hline Rocca Bernolfo & 7.034 & 44.246 & 0.251 & 0.006 & 2357 & Rock glacier \\
\hline Loroussa South & 7.028 & 44.269 & 0.109 & 0.002 & 2370 & Glacial deposit \\
\hline Cavias & 7.041 & 44.309 & 0.206 & 0.007 & 2349 & Rock glacier \\
\hline Bassura North & 6.982 & 44.345 & 0.154 & 0.003 & 2360 & Rock glacier \\
\hline Moura & 7.122 & 44.348 & 0.110 & 0.080 & 2365 & - \\
\hline Nebius & 7.119 & 44.343 & 0.122 & 0.002 & 2348 & - \\
\hline Oserot & 7.006 & 44.389 & 3.679 & 0.241 & 2373 & - \\
\hline Stau North & 6.960 & 44.335 & 0.427 & 0.022 & 2352 & Moraine \\
\hline Pilone & 6.965 & 44.337 & 0.289 & 0.022 & 2369 & Moraine \\
\hline Peroni & 6.966 & 44.402 & 1.541 & 0.146 & 2372 & - \\
\hline $\mathrm{Piz}$ & 6.995 & 44.297 & 5.657 & 0.381 & 2370 & - \\
\hline Ponte Bernardo & 6.969 & 44.304 & 1.600 & 0.043 & 2371 & - \\
\hline Puriac & 6.908 & 44.375 & 6.373 & 0.373 & 2347 & Glacial deposit \\
\hline Roburent & 6.943 & 44.415 & 3.363 & 0.155 & 2362 & - \\
\hline Nebius North & 7.114 & 44.351 & 0.450 & 0.080 & 2349 & - \\
\hline Scoletta & 6.984 & 44.306 & 0.643 & 0.016 & 2355 & - \\
\hline Serour & 7.120 & 44.361 & 0.174 & 0.005 & 2366 & - \\
\hline Tesina & 7.067 & 44.235 & 1.216 & 0.057 & 2354 & Moraine \\
\hline Valletta & 7.212 & 44.248 & 2.839 & 0.168 & 2349 & Moraine \\
\hline Panieris & 6.964 & 44.319 & 1.111 & 0.037 & 2368 & - \\
\hline Stau & 6.967 & 44.328 & 0.969 & 0.018 & 2353 & - \\
\hline Vallonetto & 7.048 & 44.368 & 0.346 & 0.007 & 2373 & Moraine \\
\hline TOTAL & - & - & 83.743 & 5.394 & - & - \\
\hline
\end{tabular}

Table 2 Name, midpoint coordinates, area, volume and ELA of 66 reconstructed YD glaciers in the Stura 
The present-day (2001-2018) precipitation at the nearby Diga del Chiotas weather station (1980 m asl, i.e. $378 \mathrm{~m}$ lower than the YD ELA) is $1487 \mathrm{~mm} / \mathrm{yr}$ and the January, July and summer (June-August) temperatures are $-1.7^{\circ} \mathrm{C}, 13.8^{\circ} \mathrm{C}$ and $12.8^{\circ} \mathrm{C}$, respectively. These temperatures, when adjusted to the elevation of the YD average ELA using the standard lapse rate, return values of $-2.8^{\circ} \mathrm{C}, 11.4^{\circ} \mathrm{C}$ and $10.4^{\circ} \mathrm{C}$ respectively, with a seasonality of $14.2^{\circ} \mathrm{C}$.

273

274

5. Discussion Well-preserved moraines associated with the Egesen stadial, the last of the Lateglacial stadials in the European Alps, are common (Ivy Ochs et al., 2009). They are recognised as the first prominent, blocky, usually multi-crested moraine set that can be found downvalley from the Little Ice Age moraine (Ivy-Ochs, 2015). The FER moraine fits this description: it is the first moraine set that can be found (about $2 \mathrm{~km}$ ) downvalley from the Holocene moraines in the Val Forneris; its aspect, characterised by very large boulders, resembles that of many other Alpine Egesen moraines (see Figure 4 in Hormes et al., 2008); the presence of nearby moraines, most likely connected to the same climatic event, is also a typical trait of the Egesen geomorphological signature across the Alps (Ivy Ochs, 2015). A handful of Egesen stadial moraines has so far been dated with cosmogenic isotope exposure dating techniques, all returning an age compatible with the YD (Baroni et al., 2017; Böhlert et al., 2011a; Cossart et al., 2012; Federici et al., 2008; Hormes et al., 2008; Ivy-Ochs et al., 1996; 2006; 2009; Kelly et al., 2004; Moran et al., 2016; Schindelwig et al., 2012). The FER moraine, dated here to the YD, is an important addition to this sparse database. It provides further evidence that the Egesen stadial in the European Alps actually represents the glaciological and morphological expression of the YD cooling event. It also allows for the reconstruction of several potential YD/Egesen glaciers within its neighbourhood and its ELA can be used to extract YD climatic conditions in this sector of the Alps.

\subsection{Climate}

A proper comparison of ELA values across the Alps for the YD is beyond the scope of this work and would require a consistent reconstruction of all YD palaeoglaciers and the extraction of their ELA with a same approach. However, different ELA calculation approaches would typically account for ELA discrepancy of the order of some tens of meters, for alpine valley glaciers of the size considered here (e.g. Federici et al., 2017; Scotti et al., 2017). The average ELA (2358 $\mathrm{m}$ asl) of the two YD reconstructed glaciers of the Maritime Alps is a few hundred meters lower than the ELA reported from other Alpine sectors for this same glacier stadial (Baroni et al., 2017; Scotti et al., 2017). This difference is an order of magnitude greater than a potential methodologically-related discrepancy, indicating that the climatic conditions of the Maritime Alps at the YD were peculiar within the context of the Alps. In an 
alpine environment, the ELA of a valley glacier is largely controlled by the summer temperature, which influences glacier ablation; and by solid, typically winter, precipitation, which affects ice accumulation. The lower YD ELA of the Maritime Alps therefore reflects lower summer temperature and/or higher solid precipitation, relative to the rest of the Alps.

The climatic reconstruction attempted here shows increased seasonality $\left(6.8^{\circ} \mathrm{C}\right.$ higher, relative to present-day measurements) and a considerable drop in temperature at the YD $\left(8.1^{\circ} \mathrm{C}\right.$ lower in July and $14.9^{\circ} \mathrm{C}$ lower in January, relative to present-day measurements), in line with other Alpine YD palaeoclimate studies (e.g. Lotter et al., 2000; Heiri et al., 2014b). However, it is the relatively high YD precipitation, comparable to the present-day precipitation, that makes the YD climate of the Maritime Alps peculiar within the context of the wider Alps. This is in apparent disagreement with the paradigm of a widespread arid YD across most of Europe and the Alps (e.g. Heiri et al., 2014a and b; Magny et al., 2001), including its SW sector (Ortu et al., 2008; Brisset et al., 2015); however, a previous attempt to reconstruct palaeoprecipitation based on YD glacier ELA has highlighted considerable variability in the central Alps, including regions where YD precipitation was similar to, and even higher than, present-day precipitation (Kerschner, 1981; Kerschner et al., 2000; Kerschner \& Ivy-Ochs, 2008).

The Maritime Alps YD climate reconstruction is based on at least three aspects that can be challenged. Firstly, the YD relationship between temperature and precipitation at the ELA may have been different from today's. Nonetheless, it is hard to physically justify such a scenario, as the law is robustly based on current worldwide empirical observations, not specific to an individual site and considering multi-decadal data (Ohmura and Boettcher, 2018). Secondly, the chironomid-derived YD $\mathrm{T}_{\text {Jul }}$ might reflect local conditions only, thus questioning its validity for the calculation of temperatures for a site that is $95 \mathrm{~km}$ away and at an elevation almost $2000 \mathrm{~m}$ higher. Thirdly, the pollen-derived YD $\mathrm{T}_{\mathrm{Jan}}$, although relative to a site located within the Maritime Alps and at an elevation similar to the YD ELA, might not be reliable since the approach suffers from lack of good analogues, problems with pollen taxa and complexity of mountain ecosystems (e.g. Ortu et al., 2006). Despite these potential limitations, it should be noted that a recent study, based on fossil trees from a location $\sim 90 \mathrm{~km}$ west of our site, also indicates non-arid conditions for this region at the onset of the YD (Pauly et al., 2018). These conditions are interpreted as the effect of more frequent and/or intense precipitations originating from North Atlantic air masses, combined with more intense winter storms resulting from the interaction between cold high-latitude and warm Mediterranean air masses, along the margin of the southward-displaced polar front (Pauly et al., 2018). Such an interpretation fits very well with the uniqueness of the Maritime Alps YD glaciers within the context of the wider Alpine region, because of their closer proximity to both the Mediterranean Sea and the Atlantic Ocean. 
337 This paper represents the first attempt at using the GIS GlaRe tool (Pellitero et al., 2016) to model the extent of all palaeoglaciers belonging to the same stadial in an extensive alpine region, using the ELA of nearby palaeoglaciers associated with moraines also dated to that stadial. Although the trial-anderror approach (by iteration of the glacier front position) is time-consuming, the reconstruction of 66 glaciers took some weeks against the months it would have probably taken using the classic manual topographic approach (e.g. Porter et al., 1975; Carr et al., 2010), i.e. without the use of GlaRe. Most importantly, GlaRe implements a physically-plausible plastic rheology glacier model for the glacier reconstruction, thus giving further robustness to the results. The application of a regional ELA interval defined by two dated moraines is questionable, since it is possible that ELA variability exceeded these boundaries across the 66 glaciers. However, the defined interval allows us to provide a first order model of the YD expansion and could be useful for further, more detailed studies. 

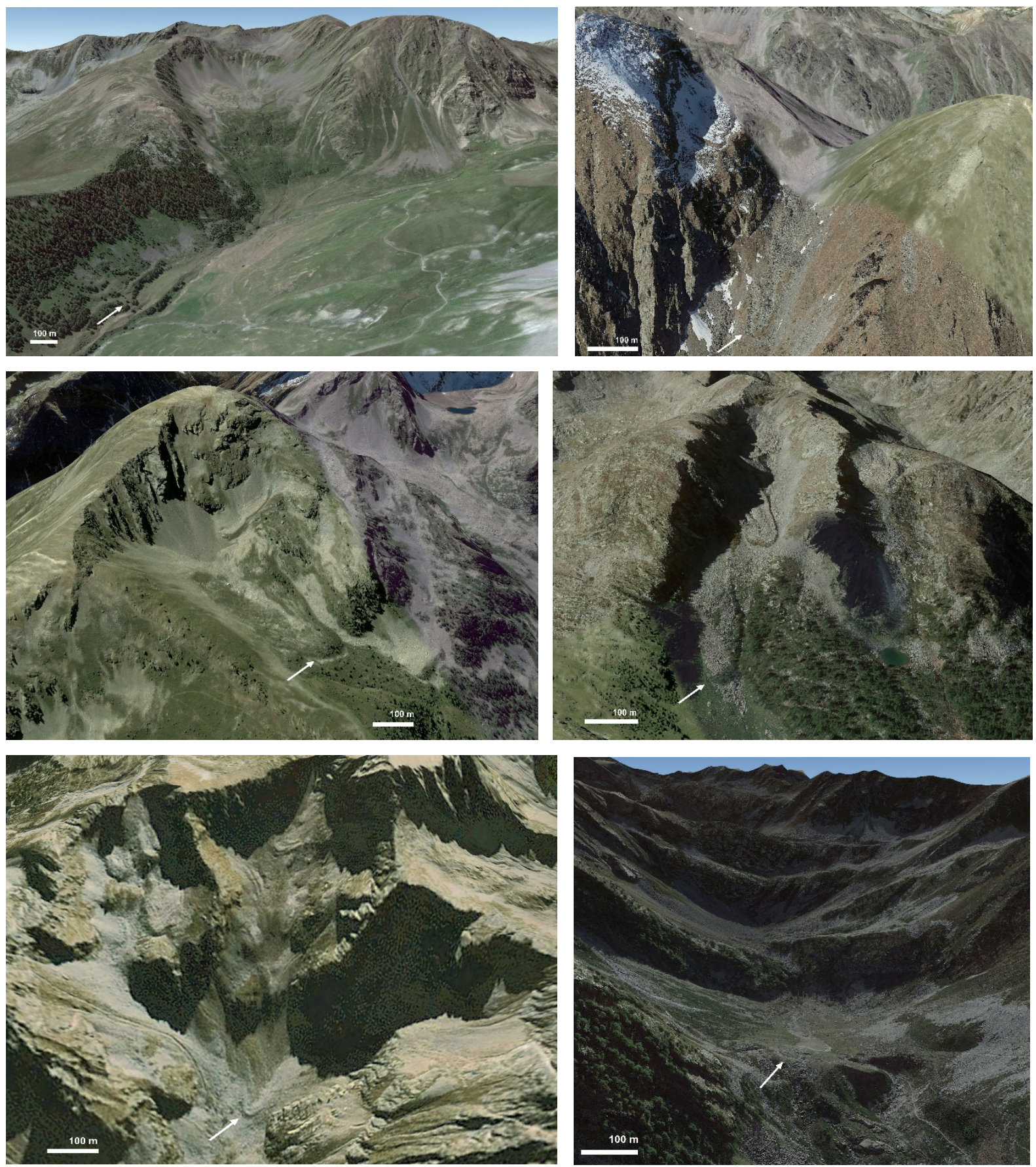

Figure 4. Examples of identified moraines on Google Earth ${ }^{\mathrm{TM}}$ located at the front (ice margin) of the reconstructed YD glaciers in the Stura catchments. Top left: Ferrere glacier (the approximate coordinates of the moraine are $\left.44.35^{\circ} \mathrm{N}, 6.95^{\circ} \mathrm{E}\right)$; Top right: Laorussa South glacier $\left(44.27^{\circ} \mathrm{N}, 7.03^{\circ} \mathrm{E}\right)$; Centre left: Saletta glacier $\left(44.28^{\circ} \mathrm{N}, 7.03^{\circ} \mathrm{E}\right)$; centre right: Pignal glacier $\left(44.25^{\circ} \mathrm{N}, 7.07^{\circ} \mathrm{E}\right)$; Bottom left: Maladecia glacier $\left(44.24^{\circ} \mathrm{N}, 7.14^{\circ} \mathrm{E}\right)$; Bottom right: Valletta glacier $\left(44.26^{\circ} \mathrm{N}, 7.21^{\circ} \mathrm{E}\right)$.

In order to test the modelled reconstruction presented here, the location of the 66-glacier front was checked in Google Earth ${ }^{\mathrm{TM}}$ and on an available geology map of the region that include some surface geology (Malaroda et al., 1970), with the aim to find evidence of a frontal moraine (Table 2). Twenty-nine percent of the settings have evidence of a moraine (Figure 4), while another $14 \%$ include glacial deposits where the morphology of a moraine could not be determined for sure, possibly an 
issue related to the resolution of the available images. In some instances (another $\sim 10 \%$ of the cases), a rock glacier is found in the vicinity of the reconstructed glacier front, possibly incorporating a potential YD moraine. This is in line with the evidence that the activity of many rock glaciers in the Alps can be traced back to the end of the YD (Ivy-Ochs et al., 2009; Böhlert et al., 2011b; Moran et al., 2016). The remaining $47 \%$ of reconstructed glaciers are characterised by the absence of a moraine or a rock glacier at their front: in many instances, the resolution of the available imagery is either not sufficiently high for the task, or the potential frontal moraine area is covered by thick vegetation. In other, locations are clearly unsuitable for the deposition or preservation of a moraine, because the valley bottom is particularly steep. If a moraine has not been identified, despite a favourable setting and good imagery, the deposit might have been eroded by post-glacial events, buried by fluvial or scree deposition. It is also possible that microclimatic conditions (e.g. those related to aspect) might have resulted in a slightly longer or shorter glacier than the reconstructed one which is based on a regional ELA and obtained using a tool, GlaRe, that does not take into consideration valley aspect. In the future, it would be interesting to improve testing by undertaking extensive field work to verify all the percentages reported above and by exposure-dating the moraines that will be identified. However, for the time being, it is encouraging to see that several potential YD moraines are present in the location identified by our modelled reconstruction (Table 2; Figure 4). This suggests that GlaRe could be used as a predictive tool for further geomorphological investigations specific to a glacial stadial for which at least one, ideally some, reliable (i.e. connected to a dated moraine) glacier reconstructions and ELA calculations are available within a same region. For example, this could be very helpful to plan fieldwork aimed at reaching other glacier front sites in nearby valleys, where potential moraines of the same age could be found, sampled and dated.

YD glacier expansion in the Stura catchment sector of the Alps was limited to about $6 \%$ of the total catchment area and confined to the highest altitudes, between 1596 and $2893 \mathrm{~m}$ asl. This is a considerable reduction when compared to the Last Glacial Maximum expansion, when the Stura, like other nearby major catchments, was occupied by a system of interconnected glaciers covering most of the catchment and extending downvalley to the mountain front at $700 \mathrm{~m}$ asl, i.e. almost reaching the Po Plain (Federici et al., 2008, 2012, 2017). Our modelled reconstruction indicates that most YD glaciers extended hundreds of metres up to a few kilometres beyond the cirques. Some neighbouring valley glaciers were connected, but not extensively enough to justify a description of the Egesen glacial stadial in the Maritime Alps as an ice field. Almost all Stura valleys were glaciated at the YD, thus considerably limiting plant/animal/human interaction, migration, communication and trading between the southern and norther sectors of this Alpine region. The configuration of the YD Stura glaciers indicates that only one pass across the main Alpine divide was then ice-free, the 
Maddalena/Larche $\left(44.42^{\circ} \mathrm{N}, 6.90^{\circ} \mathrm{E}, 1996 \mathrm{~m}\right.$ asl). This was most-likely due to its elevation, which is at least $300 \mathrm{~m}$ lower than all other main divide passes along the Stura valleys, associated with a lack of nearby, high-elevation valleys and peaks that could have sustained a glacier able to reach the pass. Ice-free Alpine passes are known to have played a crucial role in influencing pastoralism and transhumance in the Alps during the early Holocene (e.g. Hafner and Schwörer, 2018) and it is likely that they also played a role in influencing YD human activity, typically hunting and gathering. While there is only limited information available on early human presence in the Alps, evidence of YD settlements (campsites) generally linked to seasonal hunting has been recorded from various Alpine archaeological sites (Mussi and Persani, 2011; Weber et al., 2011), including the Maritime Alps (Tzortzis et al., 2008). Within this sector of the mountain chain, it is likely that human (and animal) interaction and migration across the Alpine main divide during the YD were funnelled in the Maddalena/Larche pass. This represents an ideal site for future palaeoecological, palaeozoological and archaeological investigations.

6. Conclusions

- A new Egesen stadial moraine in the Maritime Alps is dated here to $12,950 \pm 700 \mathrm{yr}$ (weighted mean value of three measurements \pm weighted standard deviation) by means of cosmogenic isotope analysis, thus adding further evidence to the link between the Egesen stadial of the European Alps and the YD cooling event.

- The YD glacier that deposited the moraine is reconstructed and its ELA calculated to $2349 \pm 5$ $\mathrm{m}$ asl. This value is very similar to the ELA (2368 $\pm 5 \mathrm{~m}$ asl) of another palaeoglacier that deposited a moraine (PDP) dated to the YD, $40 \mathrm{~km}$ to the SW. The similarity between the two ELA suggests that the region experienced similar climatic conditions during the YD.

- The average between the two ELAs ( $2358 \pm 15 \mathrm{~m}$ asl), combined with palaeotemperature data provided by independent proxies, is used to establish the Maritime Alps YD annual precipitation at the ELA, $1549 \pm 26 \mathrm{~mm} / \mathrm{yr}$, based on the empirical law that links temperature and precipitation at the ELA. Unlike most other Alpine sectors and European regions where the YD seems to be characterised by aridity, the reconstructed YD precipitation for the Maritime Alps is similar to present-day precipitation. This peculiarity is most likely related to the Maritime Alps crossroads position, which allowed the region to intercept cold and humid air masses from the Atlantic Ocean, pushed south by the displaced polar front, and warm and humid air masses from the nearby Mediterranean Sea.

- The YD ELA interval defined by the two dated moraines allows to model the extent of all potential YD glaciers (66) in the Stura catchment. The modelled location of the glaciers' front matched well with the position of actual frontal moraine and glacial deposits observed in the 

pass across the main Alpine divide, that of the Maddalena/Larche pass. This is an ideal site for

\section{ACKNOWLEDGEMENTS}

440 We would like to acknowledge: Prof. Rea and Dr Pellitero for fruitful discussions on various aspects of this work, and in particular on the use of glacier reconstruction and ELA GIS tools and extraction of climatic variables at a glacier ELA; Dr Ortu for kindly providing easy access to pollen data and for discussions on the climate of the Younger Dryas across the Alps; Prof. Edwards for discussions on pollen analyses; and Prof. Federici, for inspiring glaciological research in this beautiful region. The constructive and useful feedback provided by Dr Monegato and an anonymous reviewer is greatly appreciated. L. Cignoni is thanked for reviewing the English. MS acknowledges support from NERC (CIAF 9092.1010).

\section{REFERENCES}

Auer, I., Böhm, R., Jurkovic, A., Lipa, W., Orlik, A., Potzmann, R., Schöner, W., Ungersböck, M., Matulla, C., Briffa, K., Jones, P. D., Efthymiadis, D., Brunetti, M., Nanni, T., Maugeri, M., Mercalli, L., Mestre, O., Moisselin, J.-M., Begert, M., Müller-Westermeier, G., Kveton, V., Bochnicek, O., Stastny, P., Lapin, M., Szalai, S., Szentimrey, T., Cegnar, T., Dolinar, M., Gajic-Capka, M., Zaninovic, K., Majstorovic, Z., Nieplova, E., 2007. HISTALP - 'Historical instrumental climatological surface time series of the Greater Alpine Region 1760-2003'. Int. J. Climatol. 27, 17-46. Rutor Glacier forefield, Italian Alps. Evidence of middle Holocene timberline rise and glacier contraction. Quat. Sci. Rev. 185, 41-68. Double response of glaciers in the Upper Peio Valley (Rhaetian Alps, Italy) to the Younger Dryas profile of former mountain glaciers and ice caps. Comput. Geosci. 36, 605-610. environments. Quat. Int. 65, 15-29. 
Böhlert, R., Egli, M., Maisch, M., Brandová, D., Ivy-Ochs, S., Kubik, P.W., Haeberli, W., 2011 a. Application of a combination of dating techniques to reconstruct the Lateglacial and early Holocene landscape history of the Albula region (eastern Switzerland). Geomorphology 127, 1-13.

Böhlert, R., Compeer, M., Egli, M., Brandova, D., Maisch, M., Kubik, P.W., Haeberli, W., 2011b. A combination of relative-numerical dating methods indicates two high Alpine rock glacier activity phases after the glacier advance of the Younger Dryas. Open Geogr. J. 4, 115-130.

Boston, C. M., Lukas, S., Carr, S. J., 2015. A Younger Dryas plateau icefield in the Monadhliath, Scotland, and implications for regional palaeoclimate. Quat. Sci. Rev. 108, 139-162

Brisset, E., Guiter, F., Miramont, C., Revel, M., Anthony, E. J., Delhon, C., Arnaud, F., Malet, E., de Beaulieu, J.L., 2015. Lateglacial/Holocene environmental changes in the Mediterranean Alps inferred from lacustrine sediments. Quat. Sci. Rev., 110, 49-71.

Broecker, W.S., Denton, G.H., Edwards, R.L., Cheng, H., Alley, R.B., Putnam A.E., 2010. Putting the Younger Dryas cold event into context. Quat. Sci. Rev. 29, 1078-1081.

Brugger, K.A., 2006. Late Pleistocene climate inferred from the reconstruction of the Taylor River glacier complex, southern Sawatch Range, Colorado. Geomorphol. 75, 318-329

Cacho, I., Grimalt, J.O., Canals, M., Sbaffi, L., Shackleton, N.J., Schönfeld, J., Zahn, R., 2001. Variability of the Western Mediterranean sea surface temperature during the last 25,000 years and its connection with the Northern Hemisphere climatic changes. Paleoceanography 16, 40-52.

Carr, S.J., Lukas, S., Mills, S.C., 2010. Glacier reconstruction and mass-balance modelling as a geomorphic and palaeoclimatic tool. Earth Surf. Processes Landf. 35, 1103-1115.

Casazza, G., Grassi, F., Zecca, G., Minuto, L., 2016. Phylogeographic Insights into a peripheral refugium: the importance of cumulative effect of glaciation on the genetic structure of two endemic plants. PLoS One 11, e0166983.

Clark, P.U., Dyke, A.S., Shakun, J.D., Carlson, A.E., Clark, J., Wohlfarth, B., Mitrovica, J.X., Hostetler, S.W., McCabe, A.M., 2009. The Last Glacial Maximum. Science 325, 710-714.

Catto, N., Liverman, D.G.E., Bobrowsky, P.T., Rutter, N., 1996. Laurentide, cordilleran, and montane glaciation in the western Peace River - Grande Prairie region, Alberta and British Columbia, Canada. Quat. Int. 32, 21-32.

Cossart, E., Fort, M., Bourlès, D., Braucher, R., Perrier, R., Siame, L., 2012. Deglaciation pattern during the Lateglacial/Holocene transition in the southern French Alps. Chronological data and geographical reconstruction from the Clarée Valley (upper Durance catchment, southeastern France). Palaeogeogr., Palaeoclimatol., Palaeoecol. 315, 109-123.

Durand, Y., Laternser, M., Giraud, G., Etchevers, P., Lesaffre, B., Mérindol, L., 2009. Reanalysis of 44 yr of climate in the French Alps (1958-2002): methodology, model validation, climatology, and trends for air temperature and precipitation. J. Appl. Meteorol. Climatol. 48, 429-449.

Ehlers, J., Gibbard, P.L., 2004. Quaternary glaciations-extent and chronology: Part I: Europe. Elsevier, Amsterdam.

Federici, P.R., Pappalardo, M., Ribolini, A., 2003. Geomorphological map of the Maritime Alps Natural Park (Argentera Massif, Italy) and surroundings. Colour map, 1:25.000 scale, S.EL.CA., Firenze. 
510 Federici, P.R., Granger, D.E., Pappalardo, M., Ribolini, A., Spagnolo, M., Cyr, A. J., 2008. Exposure age 511 dating and Equilibrium Line Altitude reconstruction of an Egesen moraine in the Maritime Alps, Italy. 512 Boreas 37, 245-253.

513 Federici, P.R., Granger, D.E., Ribolini, A., Spagnolo, M., Pappalardo, M., Cyr, A.J., 2012. Last Glacial 514 Maximum and the Gschnitz stadial in the Maritime Alps according to ${ }^{10} \mathrm{Be}$ cosmogenic dating. Boreas $51541,277-291$.

516 Federici, P.R., Ribolini, A., Spagnolo, M., 2017. Glacial history of the Maritime Alps from the Last Glacial 517 Maximum to the Little Ice Age. Geol. Soc. London, Special Publication 433, 137-159.

518 Florineth, D., Schlüchter, C., 1998. Reconstructing the Last Glacial Maximum (LGM) ice surface 519 geometry and flowlines in the Central Swiss Alps. Eclogae Geol. Helv. 91, 391-407.

520 Furbish, D.J., Andrews, J.T., 1984. The use of hypsometry to indicate long term stability and response 521 of valley glaciers to changes in mass transfer. J. Glaciol. 30, 199-211.

522 Garnier, S., Alibert, P., Audiot, P., Prieur, B., Rasplus, J.-Y., 2004. Isolation by distance and sharp 523 discontinuities in gene frequencies: Implications for the phylogeography of an alpine insect species, 524 Carabus solieri. Mol. Ecol. 13, 1883-1897.

525 Golledge, N.R., Hubbard, A., Sugden, D.E., 2008. High-resolution numerical simulation of Younger 526 Dryas glaciation in Scotland. Quat. Sci. Rev. 27, 888-904.

527 Hafner, A., Schwörer, C., 2018. Vertical mobility around the high-alpine Schnidejoch Pass. Indications 528 of Neolithic and Bronze Age pastoralism in the Swiss Alps from paleoecological and archaeological 529 sources. Quat. Int. 484, 3-18.

530 Heiri, O., Brooks, S.J., Renssen, H., Bedford, A., Hazekamp, M., Ilyashuk, B., Jeffers, E.S., Lang, B., 531 Kirilova, E., Kuiper, S., Millet, L., Samartin, S., Toth, M., Verbruggen, F., Watson, J.E., Van Asch, N., 532 Lammertsma, E., Amon, L., Birks, H.H., Birks, H.J.B., Mortensen, M.F., Hoek, W.Z., Magyari, E., Munõz 533 Sobrino, C., Seppä, H., Tinner, W., Tonkov, S., Veski, S., Lotter, A.F., 2014a. Validation of climate model534 inferred regional temperature change for lateglacial Europe. Nat. Comm. 5, 4914.

535 Heiri, O., Koinig, K.A., Spötl, C. ,Barrett, S., Brauer, A.,Drescher-Schneider, R., Gaar, D., Ivy-Ochs, S., 536 Kerschner, H., Luetscher, M., Moran, A., Nicolussi , K., Preusser, F., Schmidt, R., Schoeneich, P., 537 Schwörer, C., Sprafke, T, Terhorst, B., Tinner, W., 2014b. Palaeoclimate records 60-8 ka in the Austrian 538 and Swiss Alps and their forelands. Quat. Sci. Rev. 106, 186-205.

539 Heuberger, H., 1968. Die Alpengletscher im Spät- und Postglazial. Eiszeitalter und Gegenwart 19, 270540275.

541 Hormes, A., Ivy-Och, S., Kubik, P.W., Ferreli, L., Michetti, A.M., 2008. ${ }^{10}$ Be exposure ages of a rock 542 avalanche and a late glacial moraine in Alta Valtellina, Italian Alps. Quat. Int. 190, 136-145.

543 Hughes, P.D., Braithwaite, R., 2008. Application of a degree-day model to reconstruct Pleistocene 544 glacial climates. Quat. Res. 69, 110-116.

545 Hughes, P.D., Gibbard, P.L., Ehlers, J., 2013. Timing of glaciation during the last glacial cycle: evaluating 546 the concept of a global 'Last Glacial Maximum' (LGM). Earth-Sci. Rev. 125, 171-198.

547 Hughes, P.D., Woodward, J.C., Gibbard, P.L., 2007. Middle Pleistocene cold stage climates in the 548 Mediterranean: new evidence from the glacial record. Earth Planet. Sci. Lett. 253, 50-56. 
Isola, I., Ribolini, A., Zanchetta, G., Bini, M., Regattieri, E., Drysdale, R.N., Hellstrom, J.C., Bajo, P.,

550 Montagna, P., Pons-Branchu, E., 2019. Speleothem U/Th age constraints for the Last Glacial conditions

551 in the Apuan Alps, northwestern Italy. Palaeogeog. Palaeoclimatol. Palaeoecol. 518, 62-71

552

553

554

555

556

557

558

559

560

561

562

563

564

565

566

567

568

569

570

571

572

573

574

575

576

577

578

579

580

581

582

583

584

585

586

587
Isotta, F.A., Frei, C. , Weilguni, V. , Perčec Tadić, M. , Lassègues, P. , Rudolf, B. , Pavan, V. , Cacciamani, C. , Antolini, G. , Ratto, S. M., Munari, M. , Micheletti, S. , Bonati, V. , Lussana, C. , Ronchi, C. , Panettieri, E. , Marigo, G., Vertačnik, G., 2014. The climate of daily precipitation in the Alps: development and analysis of a high-resolution grid dataset from pan-Alpine rain-gauge data. Int. J. Climatol. 34, 16571675.

Ivy-Ochs, S. 2015. Glacier variations in the European Alps at the end of the last glaciation. Cuad. Invest. Geogr. 41, 295- 315.

Ivy-Ochs, S., Schlüchter, C., Kubik, P. W., Synal, H.-A., Beer, J., Kerschner,H., 1996. The exposure age of an Egesen moraine at Julier Pass, Switzerland, measured with the cosmogenic radionuclides ${ }^{10} \mathrm{Be}$, ${ }^{26} \mathrm{Al}$ and ${ }^{36} \mathrm{Cl}$. Eclogae Geol. Helv. 89, 1049-1063.

Ivy-Ochs, S., Kerschner, H., Reuther, A., Maisch, M., Sailer, R., Schaefer, J., Kubik, P.W., Synal, H.A., Schlüchter, C., 2006. The timing of glacier advances in the northern European Alps based on surface exposure dating with cosmogenic ${ }^{10} \mathrm{Be},{ }^{26} \mathrm{Al},{ }^{36} \mathrm{Cl}$, and ${ }^{21} \mathrm{Ne}$. In: Siame, L.L., Bourle`s, D.L., Brown, E.T. (Eds.), In Situ-Produced Cosmogenic Nuclides and Quantification of Geological Processes. Geol. Soc. Am. Special Paper 415, pp. 43-60.

Ivy-Ochs, S., Kerschner, H., Maisch, M., Christl, M., Kubik, P. W., Schlüchter, C., 2009. Latest Pleistocene and Holocene glacier variations in the European Alps. Quat. Sci. Rev. 28, 2137-2149.

Kelly, M.A., Kubik, P.W., Von Blankenburg, F., Schlüchter, C. 2004. Surface exposure dating of the Great Aletsch Glacier Egesen moraine system, western Swiss Alps, using the cosmogenic nuclide ${ }^{10} \mathrm{Be}$. J. Quat. Sci. 19, 431-441.

Kerschner, H. 1981. Outlines of the climate during the Egesen Advance (Younger Dryas, 1000-10000 $\mathrm{BP}$ ) in the central Alps of the western Tyrol, Austria. Z. Gletscherkd. Glazialgeol. 16, 229-240.

Kerschner, H., Kaser, G., Sailer, R., 2000. Alpine Younger Dryas glaciers as paleo-precipitation gauges. Ann. Glaciol. 31, 80-84.

Kerschner, H., Ivy-Ochs, S., 2008. Palaeoclimate from glaciers: Examples from the Eastern Alps during the Alpine Lateglacial and early Holocene. Glob. Planet. Chang. 60, 58-71.

Kohl, C.P., Nishiizumi, K., 1992. Chemical isolation of quartz for measurement of in-situ -produced cosmogenic nuclides. Geochim. Cosmochim. Acta 56, 3583-3587.

Johnsen, S.J., Dahl-Jensen, D., Gundestrup, N., Steffensen, J.P., Clausen, H.B., Miller, H., MassonDelmotte, V., Sveinbjörnsdottir, A.E., White, J., 2001. Oxygen isotope and palaeotemperature records from six Greenland ice-core stations: Camp Century, Dye-3, GRIP, GISP2, Renland and NorthGRIP. J. Quat. Sci. 16, 299-307.

Jones, R.S., Small, D., Cahill, N., Bentley, M.J., Whitehouse, P.L., 2019. iceTEA: Tools for plotting and analysing cosmogenic-nuclide surface-exposure data from former ice margins. Quat. Geochronol. 51, 72-86. 
Larocque, I., Finsinger, W., 2008. Late-glacial chironomid-based temperature reconstructions for Lago Piccolo di Avigliana in the southwestern Alps (Italy). Palaeogeogr. Palaeoclimatol. Palaeoecol. 257, 207-223.

Lotter, A.F., Birks, H.J.B., Eicher, U., Hofmann, W., Schwander, J., Wick, L., 2000. Younger Dryas and Allerod summer temperatures at Gerzensee (Switzerland) inferred from fossil pollen and cladoceran assemblages. Palaeogeogr., Palaeoclimatol., Palaeoecol. 159, 349-361.

Magny, M., Guiot, J., Schoellammer, P., 2001. Quantitative Reconstruction of Younger Dryas to MidHolocene Paleoclimates at Le Locle, Swiss Jura, Using Pollen and Lake-Level Data. Quat. Res. 56, 170180.

Malaroda, R., Carraro, F., Dal Piaz, G.B., Franceschetti, B., Sturani, C., Zanella, E., 1970. Carta Geologica del Massiccio dell'Argentera alla scala 1:50 000 e Note Illustrative. Mem. Soc. Geol. Ital. 9, 557-663.

Meyer, M.C., Hofmann, Ch.-Ch., Gemmell, A.M.D., Haslinger, E., Häusler, H., Wangda, D., 2009. Holocene glacier fluctuations and migration of Neolithic yak pastoralists into the high valleys of northwest Bhutan. Quat. Sci. Rev. 28, 1217-1237.

Moran, A.P., Ivy-Ochs, S., Schuh, M., Christl, M., Kerschner, H., 2016. Evidence of central Alpine glacier advances during the Younger Dryas-early Holocene transition period. Boreas 45, 398-410.

Mussi, M., Peresani, M., 2011. Human settlement of Italy during the Younger Dryas. Quat. Int. 242. 360-370.

Musumeci, G., Ribolini, A., Spagnolo, M., 2003. The effects of late Alpine tectonics in the morphology of the Argentera Massif (Western Alps, Italy-France). Quat. Int. 101, 191-201.

Nishiizumi, K., Imamura, M., Caffee, M.W., Southon, J.R., Finkel, R.C., McAninch, J., 2007. Absolute calibration of ${ }^{10} \mathrm{Be}$ AMS standards. Nucl. Instrum. Methods Phys. Res. B 258, 403-413.

Ohmura, A., Kasser, P., Funk, M., 1992. Climate at the equilibrium line of glaciers. J. Glaciol. 38, 397411.

Ohmura, A., Boettcher, M., 2018. Climate on the equilibrium line altitudes of glaciers: theoretical background behind Ahlmann's P/T diagram. J. Glaciol. 64, 489-505.

Ortu, E., Brewer, S., Peyron, O., 2006. Pollen-inferred palaeoclimate reconstructions in mountain areas: Problems and perspectives. J. Quat. Sci. 21, 615-627.

Ortu, E., Peyron, O., Bordon, A., de Beaulieu, J.L., Siniscalco, C., Caramiello, R., 2008. Lateglacial and Holocene climate oscillations in the South-western Alps: An attempt at quantitative reconstruction. Quat. Int. 190, 71-88.

Osmaston, H., 2005. Estimates of glacier equilibrium line altitudes by the area_altitude, the area_altitude balance ratio and the area_altitude balance index methods and their validation. Quat. Int. 138, 22-31.

Paterson, W.S.B., 1994. The Physics of Glaciers, 3rd Edition Pergamon/Elsevier, London.

Patzelt, G., 1972. Die spätglazialen Stadien und postglazialen Schwankungen von Ostalpengletschern. Berichte der Deutschen Botanischen Gesellschaft 85, 47-57. 
Pauly, M., Helle, G., Miramont, C., Büntgen, U., Treydte, K., Reinig, F., Guibal, F., Sivan, O., Heinrich, I.,

626 Riedel, F., Kromer, B., Balanzategui, D., Wacker, L., Sookdeo, A., Brauer, A., 2018. Subfossil trees

627 suggest enhanced Mediterranean hydroclimate variability at the onset of the Younger Dryas. Sci. Rep.

$6288,13980$.

629 Pellitero, R., Rea, B.R., Spagnolo, M., Bakke, J., Hughes, P., Ivy-Ochs, S., Lukas, S., Ribolini, A., 2015. A

630 GIS tool for automatic calculation of glacier equilibrium-line altitudes. Comput. Geosci. 82, 55-62.

631 Pellitero, R., Rea, B.R., Spagnolo, M., Bakke, J., Ivy-Ochs, S., Frew, C.R., Hughes, P., Ribolini, A., Lukas, 632 S., Renssen, H., 2016. GlaRe, a GIS tool to reconstruct the 3D surface of palaeoglaciers. Comput. 633 Geosci. 94, 77-85.

634 Porter, SC., 1975. Equilibrium line altitudes of late Quaternary glaciers in the Southern Alps, New 635 Zealand. Quat. Res. 5, 27-47.

636 Ravazzi, C., Peresani, M., Pini, R., Vescovi, E., 2007. The Late Glacial in the Italian Alps and in the Po 637 Plain: Stratigraphy, vegetation history and human peopling [II Tardoglaciale nelle Alpi e in Pianura 638 Padana. Evoluzione stratigrafica, storia della vegetazione e del popolamento antropico]. Alpine 639 Mediterr. Q. 20, 163-184.

640 Renssen, H., Mairesse, A., Goosse, H., Mathiot, P., Heiri, O., Roche, D.M., Nisancioglu, K.H., Valdes, 641 P.J., 2015. Multiple causes of the Younger Dryas cold period. Nat. Geo. 8, 946-949

642 Rea, B.R., 2009. Defining modern day area-altitude balance ratios (AABRs) and their use in glacier643 climate reconstructions. Quat. Sci. Rev. 28, 237-248.

644 Rea, B.R., Evans, D.J.A., 2007. Quantifying climate and glacier mass balance in north Norway during 645 the Younger Dryas. Palaeogeogr. Palaeoclimatol. Palaeoecol. 246, 307-330.

646 Ribolini, A., 2000. Relief distribution, morphology and Cenozoic differential uplift in the Argentera 647 Massif (French-Italian Alps). Z. Geomorphol. 44, 363-378.

648 Ribolini, A., Spagnolo, M., 2008. Drainage network geometry versus tectonics in the Argentera Massif 649 (French-Italian Alps). Geomorphology 93, 253-266.

650 Schindelwig, I., Akçar, N., Kubik, P.W., Schlüchter, C., 2012. Lateglacial and early Holocene dynamics 651 of adjacent valley glaciers in the Western Swiss Alps. J. Quaternary Sci. 27, 114-124.

652 Schönswetter, P., Stehlik, I., Holderegger, R., Tribsch, A., 2005. Molecular evidence for glacial refugia 653 of mountain plants in the European Alps. Mol. Ecol. 14, 3547-3555.

654 Schorr, G., Pearman, P.B., Guisan, A., Kadereit, J.W., 2013. Combining palaeodistribution modelling 655 and phylogeographical approaches for identifying glacial refugia in Alpine Primula. J Biogeogr 40, 656 1947-60.

657 Scotti, R., Brardinoni, F., Crosta, G.B., Cola, G., Mair, V., 2017. Time constraints for post-LGM landscape 658 response to deglaciation in Val Viola, Central Italian Alps. Quat. Sci. Rev., 177, 10-33.

659 Seguinot, J., Ivy-Ochs, S., Jouvet, G., Huss, M., Funk, M., Preusser, F., 2018. Modelling last glacial cycle 660 ice dynamics in the Alps. Cryosphere 12, 3265-3285. 
661 Serrano, E., Gómez-Lende, M., González-Amuchastegui, M.J., González-García, M., González-Trueba, 662 J.J., Pellitero, R., Rico, I., 2015. Glacial chronology, environmental changes and implications for human

663 occupation during the upper Pleistocene in the eastern Cantabrian Mountains. Quat. Int. 364, 22-34

664 Shakun, J. D., Carlson, A.E., 2010. A global perspective on Last Glacial Maximum to Holocene climate 665 change. Quat. Sci. Rev. 29, 1801-1816.

666 Shilling, D.H., Hollin, J.T., 1981. Numerical reconstructions of valley glaciers and small icecaps. In: 667 Denton, G. H., Hughes, T. J. (Eds.), The Last Great Ice Sheets. Wiley, New York, 207-220.

668 Spotl, C., Mangini, A., 2007. Speleothems and glaciers. Earth Planet. Sci. Lett. 254, 323-331.

669 Stehlik, I., 2003. Resistance or emigration? Response of alpine plants to the ice ages. Taxon 52, 499670510.

671 Tzortzis, S., Mocci, F., Walsh, K., Talon, B., Court-Picon, M., Dumas, V., Py Saragaglia, V., Richer, S.,

672 2008. Les massifs de l'Argentièrois du Mésolithique au début de I'Antiquité: au croisement des 673 données archéologiques et paléoenvironnementales en haute montagne (Hautes-Alpes, parc national 674 des Ecrins). Le peuplement de l'arc alpin. Paris, Éd. du CTHS, 2008, p. 123-148.

675 van der Bilt, W.G.M., Rea, B.R., Spagnolo, M., Roerdink, D.L., Jørgensen, S.L., Bakke, J., 2018. Novel 676 sedimentological fingerprints link shifting depositional processes to Holocene climate transitions in 677 East Greenland. Glob. Planet. Chang. 164, 52-64.

678 Weber, M.-J., Grimm, S.B., Baales, M., 2011. Between warm and cold: Impact of the Younger Dryas on 679 human behavior in Central Europe. Quat. Int. 242, 277-301. 